\title{
Evaluation of Sequences of Certain Insecticide Groups and Biocide Application on Cotton Bollworms, Associated Predators and Cotton Yield in Cotton Fields Egypt \\ Somaa, H.M.H. \\ Plant Protection Research Institute, ARC, Egypt. Corresponding author:
}

\begin{abstract}
Field experiments were conducted during 2019 and 2020 seasons in Sakh Agricultural Station Farm, Kafr El-Sheikh Governorate, to evaluate the sequences of certain insecticide six groups and biocide on cotton bollworms, associated predators in cotton fields and cotton yield. Sequence of Ictafos (chlorpyrifos) of organic phosphorus - Topron (chlorofluoezuron) of insect growth inhibitor - Cyperco (cypermethrin) of pyrethroids resulted in the greatest means of reduction $(51.07,71.57$ and $83.58 \%$ ) in number of cotton pink bollworm, pectinophora gossypiella (Saund.), Spiny bollworm, Earias insulana (Boisd.) and American bollworm, Helicoverpa armigera Hubner larvae, respectively. The least means of reduction $(25.87,30.28$ and $37.78 \%)$ of number of pink, spiny and American bollworms larvae with sequence of biocide, (Agrein) only, respectively. All treatments of insecticides were associated with the greatest reduction by range of $(65.60-69.90 \%)$ and $(70.34-76.14 \%)$ on the populations of the six insect predators by the application of sequences of insecticides and each insecticide alone, respectively. Contrast, sequence of biocide Agrein had the minimum side effect on beneficial predators with mean of reduction (29.05\%). The highly effective insecticidal sequence against cotton bollworms had the highly increase in cotton yield production.
\end{abstract}

Keywords: -

Introduction

Cotton is an important fiber crop in Egypt and world. The bollworms complex, including pink bollworm (pectinophora gossypiella (Saund.)), spiny bollworm (Earias insulana (Boised.)) and American bollworm (Helicoverpa armigera Hubner) threaten to continue success of cotton production. These pests attack the fruit bodies of cotton and cause heavy losses in the yield. As a result of continuous and unregulated application of insecticides, insects began to develop high levels of resistance to insecticides. Pink bollworm exhibit resistance to quinalphos and pyrethrin in India and China (Tao et al. 2000) and Kranthi et al. (2001), spiny bollworm (E.vittella) resistance against five pyrethroid insecticides in Pakistan (Mushtaq and Arif (2009)) and the American bollworm showed high degree of resistance to Triazophos, cypermethrin, fenvalerate, quinalphos, monocrotophos, methomyl in India and pyrethroid insecticides in Cameroon (Achaleke etal. (2009), Kranthi etal. (2001)) and (Radhika and Subbaratman (2006)). In response to this problem, efforts to control or suppress bollworms, damage for growing cotton frequently involve using insecticides of different groups in rotation programme which may be useful to avoid the resistance problem. Also, the same trend was recorded by many authors (Watson etal. (1986), El-Feel etal. (1991): Khidr etal. (1996): El-Sorady etal. (1998):El-Dessouki etal (2006): El-Mageed etal. (2007): Achaleke etal. (2009) and Massoud etal. (2009). Therefore, the objective of the present work was to evaluate the efficacy of some insecticides used in seven rotations against the cotton bollworms.

\section{Materials and Methods}

The experiments were conducted during the cotton growing seasons 2019 and 2020 at Sakha Agricultural Research Station Farm, Kafr El- Sheikh Governorate. The variety of cotton was Giza 86 and the data of cultivation was from March $20^{\text {th }}$ and $30^{\text {th }}$ of the 2019 and 2020 seasons, respectively. The area of the experiments was one feddan received the normal agricultural practices during the two cotton seasons. Three recommended insecticides representing different chemical groups, Cyperco 20\% EC (cypermethrim) (pyrethroids), Ictafos $48 \%$ Ec (chlorpyrifos) (organic phosphorus) and Topron 5\% EC (Chlorofluoezuron) (Insect growth inhibitor (IGI)), and microbial insecticide (biocide), Agrein Bacillus thuringiensis (Berliner).

The sequences of insecticides and biocide were:

(1) (Cyperco - Ictafos - Topron), (2) (Ictafos Topron - Cyperco), (3) (Topron - Cyperco Ictafos), (4) (Ictafos - Ictafos - Ictafos), (5) (Cyperco - Cyperco - Cyperco), (6) (Topron - Topron Topron) and (7) (Agrein - Agrein - Agrein) .24 replicates for seven sequences of insecticides, biocide and control (three replicates for sequence).

The insecticides were applied by means of CP3 sprayer, applying 36 Liters insecticidal solution (9 Liters/ replicate). The first application was undertaken on mid-July, the interval of two weeks any two successive applications in the two seasons 2019 and 2020. Sequences were evaluated according 
to their effectiveness in reducing the number of bollworms and infestation percentages as well as cotton yield production. Samples of 75 green bolls per each treatment (25 bolls/ replicate) were randomly collected from both diagonals of the inner square area of each replicate on the day before first application and then weekly throughout the whole experimental period.

Samples of bolls were transfered to the laboratory and were examined for the actual presence of pink, spiny and American bollworms Larvae, twenty five standing cotton plants from each treatment was weekly examined to recorded the numbers of the predators (only adults) of paederus alfierii Koch., some species of Family: Coccinellidae, Chrysoperla carnea (Steph.), Ischnura senegalensis and Syrphus corollae F. during a period extended from mid-July till early October to calculate the percentage reduction in the three bollworms larvae and predators populations. Henderson and Tilton (1955) was used as follows:

$\%$ population reduction $=(1-\mathrm{A} / \mathrm{B} \times \mathrm{C} / \mathrm{D}) \times 100$ Where

A- Number of Larvae per 75 green bolls in treatment after application.

B- Number of Larvae per 75 green bolls in treatment before application.

C- Number of Larvae per 75 green bolls in check before application.

D- Number of Larvae per 75 green bolls in check after application.

At the end of 2019 and 2020 seasons, cotton yield of each treatment was weighted separately and recorded.

Duncan's multiple range test (1955) at 5\% level was used to compare the means of different treatments

\section{Results and Discussion}

\section{A- The pink bollworm, pectinophora gossypiella} (Saund.):

Data presented in Table (1) showed that, the good reduction in number of pink bollworm larvae with sequence of insecticides 2 (Ictafos (chlorpyrifos) of organic phosphorus) - Topron (chlorofluoezuron) of insect growth inhibitor) Cyperco (cypermethrin) of pyrethroids) by mean reduction $51.07 \%$ in number of Larvae, followed by sequence 4(Ictafos - Ictafos - Ictafos) and sequenece 1 (Cyperco, Ictafos - Topron) with means

(50.28 and 49.89\%), respectively. Sequence 7 (Agrein - Agrein - Agrein) of (biocides) was the least effective by mean reduction $(25.87 \%)$ in boll infestation.

Table1. Effect of insecticidal - sequence on the percentage reduction of number of bollworms larvae in green bolls and some insect predators during 2019 and 2020 cotton seasons in Sakha, Kafr El-Sheikh Governorate.

\begin{tabular}{ccccccccccccc}
\hline Insects & \multicolumn{3}{c}{ Pink bollworm } & \multicolumn{3}{c}{ Spiny bollworm } & \multicolumn{3}{c}{ American bollworm } & \multicolumn{3}{c}{ Six Insect predators } \\
\hline $\begin{array}{c}\text { Treatments } \\
\text { (sequenes) }\end{array}$ & $\mathbf{2 0 1 9}$ & $\mathbf{2 0 2 0}$ & mean & $\mathbf{2 0 1 9}$ & $\mathbf{2 0 2 0}$ & mean & $\mathbf{2 0 1 9}$ & $\mathbf{2 0 2 0}$ & mean & $\mathbf{2 0 1 9}$ & $\mathbf{2 0 2 0}$ & mean \\
\hline 1- (C-I-T) & 48.47 & 51.30 & 49.89 & 66.43 & 64.05 & 56.24 & 81.02 & 74.70 & 77.86 & 63.53 & 69.56 & 66.55 \\
2- (I-T-C) & 46.44 & 55.69 & 51.07 & 79.07 & 64.05 & 71.57 & 86.48 & 80.67 & 83.58 & 58.36 & 72.84 & 65.60 \\
3- (T-C-I) & 28.07 & 58.90 & 43.49 & 58.54 & 78.05 & 68.30 & 65.24 & 87.30 & 76.27 & 63.26 & 76.53 & 69.90 \\
4- (I-I-I) & 48.41 & 52.14 & 50.28 & 78.86 & 37.75 & 58.31 & 75.44 & 73.30 & 74.37 & 68.24 & 84.03 & 76.14 \\
5- (C-C-C) & 46.24 & 48.34 & 47.29 & 80.14 & 29.89 & 55.02 & 69.51 & 66.67 & 68.09 & 64.71 & 77.90 & 71.31 \\
6- (T-T-T) & 32.20 & 44.42 & 38.34 & 47.74 & 37.49 & 42.62 & 53.38 & 59.00 & 64.61 & 65.43 & 75.19 & 70.34 \\
7- (A-A-A) & 23.73 & 28.00 & 25.87 & 31.94 & 28.61 & 30.28 & 35.59 & 39.96 & 37.78 & 28.69 & 28.46 & 29.05 \\
\hline control & 14.75 & 16.86 & 15.80 & 8.61 & 11.71 & 10.16 & 8.43 & 10.71 & 9.57 & 53.50 & 116.60 & 85.05 \\
\hline
\end{tabular}

$\mathrm{C}=($ Cyperco) pyrethroids, I (Ictafos) organic phosphorus

$\mathrm{T}=$ (Topron) insect growth inhibitoron, (IGI), A=Agrein (Bt) Bacillus thurigiensis

Maher etal. (2004) they found the chlorpyrifos was highly effective to be more effective up to 3 weeks and caused $71.74 \%$ reduction on pink bollworm infestation in Pakistan. Massoud etal. (2009) (b) found the Agrein treatment the least reduction on pink bollworm population $(37.21 \%)$, so, the chlorpyrifos (Ictafos) treatment gave the highest infestation reduction $(74.00 \%)$ followed by cypermethrin (Cyperco) (73.91\%) in Alexandria Governorate.

\section{B- The spiny bollworm, Earias insulana (Boisd.): \\ The best sequence with mean reduction $(71.57 \%)$ of number of larvae of spiny bollworm was}

sequence 2 (Ictafos - Topron - Cyperco) in Table (1), followed by sequence 3 (Topron - Cyperco Ictafos) and sequence 1 (Cyperco - Ictafos Topron) by means $(68.30$ and $65.24 \%)$. And the least reduction in number of spiny bollworm larvae was sequence 7 of biocide with mean $(30.28 \%)$.

Maher et al. (2004) (a). Found chlorpyrifos exhibited effectiveness up to three weeks to control spotted bollworm in Pakistan.

\section{C-The American bollworm, Helicoverpa armigera Hubner:}

Data presented in Table (1) showed that the all sequences of insecticides were highly effective on 
number of larvae of American bollworm, but, the first sequence was 2 (Ictafos - Topron - Cyperco) with mean reduction $(83.58 \%)$.

Followed by sequence 1 (Cyperco - Ictafos Topron) and sequence 3 (Topron - Cyperco Ictafos) by means of reduction (77.86 and $76.27 \%)$, respectively.

So, the least mean $(37.78 \%)$ of reduction of number of American bollworm larvae with sequence biocide (7) (Agrein - Agrein - Agrein).

Kehail etal. (2007) found the (chlorpyrifos) was the most effective in controlling of the American bollworm larvae and the pyrethroid group was the least effective in controlling this pest.

Sequence 2 was the highest reduction on boll infestation by larvae of the pink, spiny and American bollworms may be to use the chlorpyrifos (Ictafos) in the $1^{\text {st }}$ spray (highly effective to be more effective up to 3 weeks), and used the sequence of different insecticides to avoid the resistance against the chlorpyrifos insecticide. And found highly significant differences between every treatments of insecticides on the three bollworms larvae (Table 3).

\section{D- The six associated insect predators:}

Data obtained from the Table (1) revealed that, all the treatments of insecticides were associated with the greatest reduction by range of $(65.60-69.90 \%)$ and $(70.34-76.14 \%)$ on the populations of the six insect predators by the application of sequences of insecticides and several the same insedicides, respectively. The predators were (Paederus alfierii Koch., two species of Family: Coccinellidae, Chrysoperla carnea (Steph.), Ischnura senegalensis and Syrphus corollae F.), and found unsignificant differences between every treatments of insecticides (Table 3) . Contrast, sequence of biocide Agrein had the minimum side effect on beneficial predators with mean of reduction $(29.05 \%)$.

This results agreed with El-Dessouki etal. (2006), Younis etal. (2007) and Kumar and Stanley (2010).

\section{E- Effect of the sequences of insecticides on cotton yield:}

As regards the yield of cotton, data presented in Table (2) indicated that, the highly reductions of cotton bollworms infestation lead to highly increased the yield over that of the control. And found highly significant differences between every treatments in the two seasons 2019 and 2020, for 48.77 (Table 3).

The sequence 2 (Ictafos - Topron - Cyperco) was highly increased in cotton yield production over that of the control with mean $(315.91 \%)$ in the two seasons (2019 and 2020), and the least increased in cotton yield production $(14.27 \%)$ by sequence of biocide Agrein. This results agreed with El Dessouki etal. (2006) and younis etal. (2007).

Table 2. Effect of insecticidal - sequences on the percentage increased the yield of cotton over that of the control / 25 plants during 2019 and 2020 cotton seasons in Sakha, Kafr El-Sheikh Governorate.

\begin{tabular}{ccccccccc}
\hline Treatments & Sequence & Sequence & Sequence & Sequence & Sequence & Sequence & Sequence \\
year & $\mathbf{1}$ & $\mathbf{2}$ & $\mathbf{3}$ & $\mathbf{4}$ & $\mathbf{5}$ & $\mathbf{6}$ & $\mathbf{7}$ & Control \\
(C-I-T) & $(\mathbf{I}-\mathbf{T}-\mathbf{C})$ & $\mathbf{( T - C}-\mathbf{I})$ & $(\mathbf{I - I}-\mathbf{I})$ & (C-C-C) & (T-T-T) & (A-A-A) & \\
\hline $\mathbf{2 0 1 9}$ & 208.33 & 216.66 & 225.00 & 95.83 & 91.67 & 100.00 & 25.00 & 60.00 \\
$\mathbf{2 0 2 0}$ & 167.68 & 415.15 & 258.59 & 122.22 & 96.97 & 112.12 & 3.54 & 198.00 \\
Mean & 188.01 & 315.91 & 241.80 & 109.03 & 94.32 & 106.06 & 14.27 & 129.00 \\
\hline \multicolumn{7}{c}{ C= (Cyperco) pyrethroids, I (Ictafos) organic phosphorus } \\
T= (Topron) insect growth inhibitor, (IGI), A=Agrein (Bt) Bacillus thurigiensis &
\end{tabular}

Table 3. Combined analysis of variance of eight treatments for four treatments over two years

\begin{tabular}{lllllll}
\hline \multicolumn{1}{c}{ S.O.V. } & d.f. & $\begin{array}{c}\text { No. of PBW } \\
\text { Larvae / 25 } \\
\text { bolls }\end{array}$ & $\begin{array}{c}\text { No. of SBW } \\
\text { Larvae / 25 } \\
\text { bolls }\end{array}$ & $\begin{array}{c}\text { No. of ABW } \\
\text { Larvae / 25 } \\
\text { bolls }\end{array}$ & yield & $\begin{array}{c}\text { Six insect } \\
\text { predators }\end{array}$ \\
\hline Years (y) & 1 & $438.52^{* *}$ & $68.41^{* *}$ & $49.48^{* *}$ & $123.81^{* *}$ & $38.21^{*}$ \\
Error & 8 & 11.20 & 35.15 & 39.81 & 0.22 & 31.11 \\
Treatments (T) & 7 & $15252.30^{* *}$ & $5601.71^{* *}$ & $5410.52^{* *}$ & $48.77^{* *}$ & 460.15 \\
$(\mathrm{y} \times \mathrm{T})$ & 7 & $41.87^{*}$ & $49.11^{* *}$ & $40.53^{*}$ & $3.06^{* *}$ & $40.22^{*}$ \\
Error & 56 & 18.70 & 12.64 & 19.18 & 0.19 & 18.10 \\
C.V.\% & & 15.20 & 17.51 & 23.10 & $8.5 \%$ & 17.30 \\
\hline
\end{tabular}




\section{References}

Achaleke, J.;M., Vaissayre and T., Brevault (2009). Evaluating pyrethroid alternatives for management of cotton bollworms and resistance in Cameroon. Experimental Agric. 45: 1,35 - 46.

El-Dessouki, S.A.; A.S. El-Khouly; A.A.S. ,El Zanan and H.M.H. ,Somaa (2006). Effect of some insecticides sequences against cotton bollworms larvae, non-target insects and associated predators in cotton fields. Egypt.J.Agric. Res., 84 (5), 1451 -1462 .

El-Feel, E.A; A.A., Khidr; M.M., Abou-Kahla and M.G., Abbass (1991). Effect of insecticidal sequence, time intervals between spray and early spray on the pink bollworm, Pectinophora gossypiella (Saunders) and cotton yield. Egypt. Agric. Res. Rev., 67: 1- 11.

El-Mageed, A.E.M.A.; E.M.. Anwar; L.R.A., El gohary and H.F., Dahi (2007). Evaluation of several programs of sequences pesticides application on cotton bollworms and some other sucking pest in cotton field.J. of Entom. 4: 2, 93 103.

El-Sorady, A.E.M., A.A.S., El-Zanan, M.K.A., AboShloa and A.A., El-Dahan (1998). Influence of some insecticide sequences on natural and artificial infestation with pink bollworm, pectinophora gossypiella (Saund.). Egypt. J. Agric. Res., 76 (2), 585 - 597.

Henderson, C.F. and Tilton (1955). Test with acaricides against the brown wheat mite.J.Econ. Entomol., 48: 157 - 161.

Kehail; S.A.A, Y.O.H., Assad and E.M.A., Eltoum (2007). Susceptibility of the African bollworm, Helicoverpa armigera (Hub.) to endosulfan, chlorpyrifos, carbosulfan and fenpropathrin using different bioassay methods. Resistant pest management News Letter 17:1, 12 - 19.

Khidr; A.A; W.M.H., Desuky, A.A., El-Sheakh and S.A., Raslan (1996). Sequential use of some insecticides against cotton bollworms in control trials. Egypt.J.Agric. Res., 74 (2), 321 - 331.

Kranthi; K.R, D.R., Jadhav; R.R.Wanjari, S.S., Ali and D,Russell (2001). Carbamate and organophosphate resistance in cotton pests in India, 1995 to 1999. Bull. of Entom. Res., 19 (1): $37-46$.

Kumar, K.R. and Shaleesha Stanley (2010). Bioefficacy of microbial and chemical insecticides on major Lepidopterous pests of cotton and their (insect) natural enemies in cotton ecosystem in Tamil Nadu. Resistant Pest Management Newsletter, 20:1,4 - 7 .

Mahar, A.N, M. ; Munir; D.A., Darban; A.Q., Mahar and G.S., Markhand (2004) (a) comparative efficacy of different insecticides against spotted bollworms, Earias insulana and E. Vittella on different cotton varieties in Sindh, Pakistan. Indus cottons: 1 (2): $80-87$.

Mahar; A.N.: M, Munir; D.A., Darban; A.Q., Mahar and G.S., Markhand (2004) (b). Field evaluation of different insecticides against pink bollworm on four cotton varieties in Sindh, Pakistan. Sarhad J. of Agric, 28 (1): 57 - 62.

Massoud, M.A.Z; M.M., Ibrahim; M.M., Shekeban and H.M., Ebed (2009). Effect of three insecticides and two insecticides alternatives on the pink bollworm. Alexa.J. of Agric. Res. 54: 1, $155-163$.

Mushtaq; A. and M.I., Arif (2009). Resistance of Pakistani field populations of spotted bollworm, Earias vittella (Fib). (Lepidoptera: Noctuidae) to pyrethroid, organo phosphorus and new chemical insecticides. Pest Management Science. 65: 4, $433-439$.

Radhika, P. and G.V., Subbaratnam (2006). Insecticide resistance management in cotton Indian scenario - areview. Agric. Reviews. 27: 3, $157-169$.

Tao, Y.Y; Z., Mingttua and W., Donghua (2000). Yearly changes of the control effects of pyrethrins insecticides on platyedra gossypiella Saunders. (Chinese). Jiangsu J. of Agric. Scie.; 16 (2): $92-96$.

Watson, M.W.; M.W., Guirgius; Amira M., Rashad and Nagwa M., Hussein (1986). Potencies of certain insecticides against the pink bollworm, pectinophora gossypiella (Saund.) as influenced by chemical programme in Egypt. Bull. Soc. Ent. Egypte, 15: $79-86$.

Younis, A.M.; S.H.H., Hamouda; S.A., Ibrahim and Z.A.M., Zeitoun (2007). Field evaluation of certain pesticides against the cotton bollworms with special reference to their negative impact on beneficial arthropoda (2006 cotton season, Minia region, Egypt). $8^{\text {th }}$ African Crop Science Society Conference, El-Minia, Egypt, 27 - 31 October 2007. $993-1002$. 


\section{تقييم تتابع تطبيق بعض مجاميع المبيدات الكيماوية والحيوية على ديدان اللوز والمفترسات المشتركة معها وإنتاج القطن في حقول القطن في مصر \\ حسن محمد حسن صوميع \\ معهد بحوث وقاية النباتات - مركز البحوث الزراعية - مصر مدر}

أجريت هذه التجارب الحقلية خلال موسمين 2019 م و 2020 م في محطة البحوث الزراعية بسخا بمحافظة كفر الثيخ لتقييم تأثير تتابع بعض مجاميع المبيدات والمبيدات الحيوية على ديدان اللوز والمفترسات المشتركة معها في حقول القطن ومحصول القواب القطن.

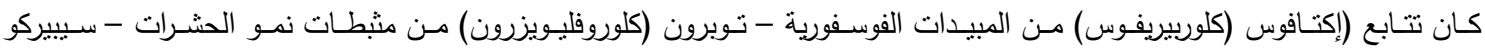
(سيبيرميثرين) من مبيدات البيروثرويد) له أكبر متوسطات خفض (51,07\% ، 871,57\% ، 83,58\%) في الاصابة بدودة اللوز الفرنفلية ودودة اللوز الثوكية ودودة اللوز الامريكية بالتزتيب.

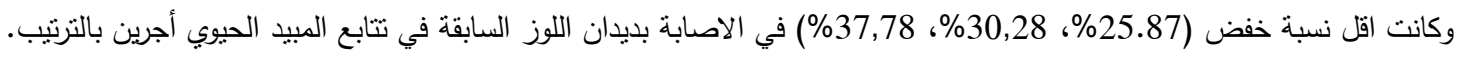

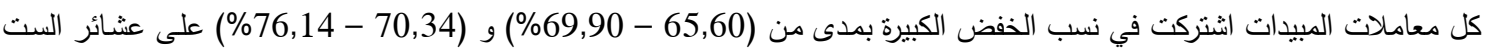
مفترسات الحشرية بواسطة تنابع المبيدات ونفس المبيدات المستخدمة فردياً بالتزتيب.

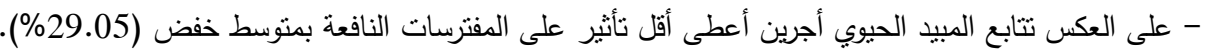
التتابعات الأعلى ثأثيراً ضد ديدان اللوز كانت الاعلى زيادة في محصول القطن بالمقارنة بالكنترول. 